\title{
Working conditions and their impact on work satisfaction in migrating and non-migrating workers. Factor structure of the Polish version of the Working Conditions Questionnaire
}

\begin{abstract}
BACKGROUND
The study compares the impact of working conditions and wages as predictors of work satisfaction of Poles, working in Poland and abroad. Although the work environment plays a crucial role in determining the work satisfaction of migrants, most mention higher income abroad as the main migration motive. The increased income may not boost the work satisfaction however, because during migration the wage reference point changes. Based on those observations, it was assumed that working conditions will have a greater impact on migrants' work satisfaction than nominal earnings. Additionally, migrants, while having higher nominal wages, should subjectively judge them as lower.
\end{abstract}

\section{PARTICIPANTS AND PROCEDURE}

Two samples - 351 subjects working in Poland, and 158 working in the UK and Germany - were analyzed. Everyone filled in an online survey including questions about their work environment and income, the Polish versions of the Working Conditions Questionnaire and the Work Satisfaction Scale. The results of the structural analyses (EFA and CFA) and between-sample measurement invariance of the Working Conditions Questionnaire were obtained. Migrants and stayers were compared us- ing a Kruskal-Wallis ANOVA. The impact of working conditions and wages on work satisfaction was analyzed with multiple linear regression.

\section{RESULTS}

The factorial structure of the Working Conditions Questionnaire in the Polish version is comparable to the Spanish original. Additionally, the nominal wages were perceived as higher for migrants than stayers. The reverse was true for subjective wage evaluations. Some working conditions were shown to have a significant impact on work satisfaction.

\section{CONCLUSIONS}

The Polish version of the Working Conditions Questionnaire is an internally consistent and reliable tool for measuring work properties. Higher nominal wages of migrants do not lead to their higher work satisfaction. Working conditions are a better predictor of work satisfaction than wages for all analyzed groups.

KEY WORDS

job satisfaction; work migration; wage evaluation

ORganization - 1: Insitute of Psychology, University of Opole, Opole, Poland · 2: Department of Social Psychology,

Social Work, Social Anthropology and East Asian Studies, University of Malaga, Malaga, Spain

AUthors' CONTRibutions - A: Study design - B: Data collection - C: Statistical analysis - D: Data interpretation .

E: Manuscript preparation · F: Literature search · G: Funds collection

Corresponding AUthor - Radosław B. Walczak, Ph.D., Insititute of Psychology, University of Opole, 1 Staszica Square,

45-052 Opole, Poland, e-mail: rwalczak@uni.opole.pl

TO CITE THIS ARTICLE - Walczak, R. B., \& Vallejo-Martín, M. (2021). Working conditions and their impact on work

satisfaction in migrating and non-migrating workers. Factor structure of the Polish version of the Working

Conditions Questionnaire. Health Psychology Report, 9(1), 87-100. https://doi.org/10.5114/hpr.2020.99208

RECEIVED 12.05.2020 • REVIEWED 21.07.2020 • ACCEPTED 26.07.2020 • PUBLISHED 01.10.2020 


\section{BACKGROUND}

Since the acceptance of Poland into the European Union in 2004, a big wave of Poles has left the country, seeking better work opportunities abroad. It is estimated that there are currently more than two million Poles, working abroad, with the biggest groups in Germany and the United Kingdom (about 700,000 in each of those countries; Kostrzewa \& Gudaszewski, 2019). The sheer number of emi-
Radosław

B. Walczak,

Macarena Vallejo-Martín grants raises the question what the motives for the decision to migrate are. A good base to use when evaluating contemporary migration is the transnationalism perspective (Portes et al., 1999). It suggests a broad look at the whole migration process, as it is nowadays relatively easy to be almost simultaneously in two worlds, working and living in one country while maintaining the social relations and cultural values of the home country. This perspective can be extended by the classical microeconomic theory of migration (Sjaastad, 1962; Massey et al., 1993), which suggests that the main reason for going abroad to work is the desire to obtain higher wages, as compared to those attainable in the home country. The interesting aspect of this theory is that it assumes that people will include other costs of migration in their deliberations. Those costs include limiting the social ties in the home country and potentially rebuilding them in the host country or the cost of adaptation to the new work environment. Those and other factors (see Massey et al., 1993 for a review) are in turn influenced by individual differences, which may cause different evaluations of similar migration conditions between different people. What is important, the list of psychological factors influencing the evaluation of a decision to migrate is not closed. Massey and colleagues (1993) indicate that the psychological conditions may outweigh the differences in earnings between home and host countries, but they do not specify which psychological elements may be taken into considerations. This opens a possibility to extend the microeconomic theory, specifying the importance of different psychological and social aspects of migration's evaluation.

One of the early attempts to go beyond money as the main driver for migration was made by Winchie and Carment (1989). They asked a group of 380 Indians applying for a Canadian visa to rank their reasons for migrating. The top three reasons (from a list of 17) were in order: a lack of opportunities for advancement, a lack of suitable employment, and only in the third place an inadequate income. Such an order of factors suggests that money, while being important, is not the primary motive for seeking a job abroad. Therefore it might be interesting to look at all other remaining work properties, to find the true reasons for the choice of country to work in.

\section{WORKING CONDITIONS}

A literature review shows a broad spectrum of factors that, besides money, influence the work evaluation in the eyes of individuals. Wang and Jing (2018) group all factors influencing migrant work evaluation in three areas: work environment, job characteristics, and work-specific personal factors. Work environment pertains to such elements as management practices (Mudor, 2011), work and organization climate (Muchinsky, 1977; Lubrańska, 2011), and social relations at work (Hodson, 1997; Szostek \& Glińska-Neweś, 2017). The interaction between those base properties may be related to a range of workplace effects, important for migrant workers, both negative such as workplace discrimination (Wrench et al., 2016) and positive, for example, workplace support (Hombrados-Mendieta \& Cosano-Rivas, 2013). In general, the expectations towards a better work environment may be a factor pushing people abroad, especially for people who believe that the home country work environment is suboptimal. The second group of migrants' work conditions mentioned by Wang and Jing (2018) are the job characteristics. They include the often studied characteristics described by Hackman and Oldham (1980), that is skill variety, task identity, task significance, work autonomy and feedback, of which autonomy seems to be most relevant for migrant workers (Itzhaki et al., 2013). Work autonomy plays such an important role because other characteristics mentioned by Hackman and Oldham (1980) may be more dependent on individual expectations towards a given job, rather than country-specific effects (Walczak, 2013). Other work characteristics potentially important for migrant workers include salary, job demands, job control, and development possibilities (Wang \& Jing, 2018). Of those, one of the most studied characteristics is of course monetary compensation. Already in the conceptualization of Herzberg (1973) money was included as a hygiene factor, that is a property needed for the lack of dissatisfaction, but not sufficient to increase satisfaction. As discussed previously (Winchie \& Carment, 1989) even migrants themselves may not perceive their expected salary as the most important migration factor. Many studies show (Kahneman \& Deaton, 2010; Peiró et al., 2010; Walczak, 2016, 2017) that money has a limited effect on work evaluation. It may be important as a basic prerequisite, but after a certain income level is secured, money stops influencing the work evaluation. This threshold level corresponds to a wage slightly higher than the average income, equaling approx. U\$75,000 a year in the USA in 2009 (Kahneman \& Deaton, 2010) and approximately 5000 PLN a month in Poland in 2015 (Walczak, 2016). Since salaries are always nominally higher in the host country compared to the home country, they may still 
have some impact on the decision to migrate (Work Service, 2014) and job satisfaction evaluation (see for example Itzhaki et al., 2013). But they should not be the most important factor, when other work characteristics are concerned. On top of that, the reference point for judging monetary compensation differs in the home country and the host country. People who do not migrate can compare their wages with other people working in the same country, in similar positions (Clark et al., 2009; Walczak, 2017). Migrants (and potential migrants) might however have a different point of reference, as they compare the wage levels of two countries. All those considerations point to the fact that the nominal wage level may be of quite a low importance (as low as .15 in job satisfaction evaluation; Judge et al., 2010), especially when compared with relative wages or other work properties.

Wang and Jing (2018) also mention the job demands and job control as important work characteristics for migrant work evaluations. Those properties reflect the skill and effort requirements of a given job, and the perceived ability to influence and manage what is being done. Both dimensions can be well connected with both work satisfaction and other work effects, which is well described in the job demands-resources model (Bakker \& Demerouti, 2017; Qin et al., 2014; Baka, 2018). That model states, in short, that both the burdens of work and around it, called work demands, and the work positives, called work resources, have to be taken into account simultaneously, to determine the work effects, that is either satisfaction as the positive consequence, or burnout as the negative. Qin et al. (2014) have used this model to successfully predict home return intentions in Chinese internal migrants, and it may also be helpful to analyze multiple work properties when studying migrants' work evaluation.

The last group of work conditions important for migrants and mentioned by Wang and Jing (2018) comprises the work-specific personal factors. Those include the workers' competency, work-related stress (Yao et al., 2015), organizational commitment (Meyer \& Allen, 1991; Bańka et al., 2002) and other work-specific characteristics. Especially competencies may play an important role in migrants' work evaluation. Due to the need for a fresh start in the new country, many migrants may find themselves to be overqualified for the job they are performing in the host country. This in turn may lead to greater work stress, related to the rust-out syndrome (Leider \& Buchholz, 1995). All other personal factors may be similarly related to migrant workers' satisfaction. The study of Chan and Qiu (2011) showed, for example, that a greater migrant tenure was related to higher work commitment, which in turn predicted higher work satisfaction.
In summary, the different dimensions of work conditions may play a decisive role in the migrants' work evaluation. In many cases they may have a greater summary effect than just the migrants' wage, leading to differentiated work satisfaction, which will be scrutinized in the next section.

\section{WORK SATISFACTION}

Work satisfaction may be defined as a positive evaluation of a person's current occupation (Spector, 1997; Zalewska, 2003). It can be judged both from an emotional perspective (how do I feel about my job, what kind of emotions do I feel in my job?) and from a cognitive perspective (what do I think about my work, how do I evaluate my job?). Both perspectives are related, but not equal (Weiss, 2002). Researchers have identified many antecedents and consequences of job satisfaction. The determinants can be further divided into situational and dispositional, with the former being represented by various work properties, as described in the previous section, and the later boiling down to the individual psychological differences. Both situational and dispositional determinants have different explanatory power over job satisfaction, with possible interactions among them. In a study by Cohrs et al. (2006) the selected environmental factors were responsible for up to $22 \%$ of job satisfaction and the personal variables for up to $12 \%$ of the variance. Another study (Pujol-Cols \& Dabos, 2019) found however those factors to be comparable, which suggest that the selection and measurement of appropriate indicators may play a decisive role in their mutual comparison.

From the consequences of job satisfaction, we can distinguish organizational and personal ones. Quite an important organizational consequence of job satisfaction is the work performance, which is often labeled as the happy-productive worker hypothesis. Earlier (Vroom, 1967) and more current (Wright \& Cropanzano, 2007; Taris \& Schreurs, 2009) studies seem to confirm the positive relation of satisfaction and performance, suggesting that this issue may also be important for organizations employing migrants. From the individual consequences of work satisfaction, we should distinguish the quality of life, a general indicator of the good life, of which work is an important part (Hulin, 1969; Judge \& Watanabe, 1993; Zdybek \& Walczak, 2009). From this perspective, the work satisfaction of migrants should be treated as a partial indicator of their general potential to be happy, and therefore an important argument in the decision whether to migrate or not.

Summing up, the migrants' work satisfaction is an important indicator of the quality of their work, and may have high importance for the whole migration evaluation.
Working conditions and work satisfaction in Poland and abroad 


\section{SUMMARY AND HYPOTHESES}

Work satisfaction seems to be the key work evaluation, highly appropriate as an indicator of the migrant workplace quality. It may be related to various work properties, some of which are significantly different for stayers and leavers. The most often studied work characteristic is the wage, and it seems appropriate to include it as one of the determining variables. On the other hand, most work evaluation models consider multiple parameters as determinants, with a special emphasis on a broad spectrum of work conditions (Herzberg, 1973; Bakker \& Demerouti, 2017; Wang \& Jing, 2018). Taking this into consideration, we decided to include a broad evaluation of working conditions in our study as well. Based on the studies of Winchie and Carment (1989) and Herzberg (1973), we assumed that wages will not be the most important factor in determining work satisfaction. Specifically, we assumed that other working conditions will have a greater impact on work satisfaction than wages. Additionally, we assumed, based on Clark's studies (Clark et al., 2009; Clark, 2011), that subjectively evaluated wages will be more important than nominal earnings in determining migrants' work satisfaction. On top of that, we assumed that migrants compared to stayers, despite having higher nominal earnings (Work Service, 2014), will perceive them as subjectively lower, due to a different comparison base.

\section{PARTICIPANTS AND PROCEDURE}

\section{PARTICIPANTS}

Two samples were analyzed in the study. Participants in the first sample were recruited by students during the spring term of 2018. All recruiters received partial course credits for their work. There was no incentive given to respondents for taking part in the study. The responses from 627 adults, working in various companies in Poland, were gathered this way. This data set was cleaned, removing all the records with missing data, all records of people working on a less than part-time basis (i.e. less than 20 hours a week), and all records of people declaring wages below the official minimum wage (2100 PLN at the moment of data collection). The resulting sample consisted of 351 employed adults, with a mean age of $32.7(S D=9.8)$ years, and an average of $10.9(S D=10.0)$ years of work experience. There were 197 females and 154 males in the group. This sample will be henceforth referred to as the Polish sample.

The second sample was recruited from the extended social network of the first author during the second half of 2018. Additionally, various associations of Poles working in the UK and Germany were contacted, with the request to forward the study questionnaire to its members. By those means it was possible to gather responses from 216 Poles working abroad. This data set was cleaned similarly as the Polish sample, yielding a sample of 158 people, working in various companies in the UK ( $n=93$, including 80 females) and Germany ( $n=65$, including 31 females). The average age was not significantly different between the German sample and the Polish one $(M=34.3, S D=11.3, Z=0.82$, $p=.414$, ns vs. PL), but it was slightly higher in the UK sample $(M=33.1, S D=6.9, Z=2.09, p=.036)$. This was also true for work experience, with an average of 12.0 $(S D=11.1, Z=0.65, p=.514$, ns vs. $\mathrm{PL}$ ) years in the German sample and $11.4(S D=6.4, Z=2.62, p=.009$ vs. PL) years in the UK sample.

All the research participants were assured about the confidentiality of their responses in the introductory part of the questionnaire. All the information was kept anonymous and no identifying information about the participants was collected.

\section{MEASUREMENTS}

In both samples, the research participants were asked to fill a similar set of questionnaires, posted on the Google Forms platform. After responding to a set of sociodemographic questions concerning both the research participants and their work, all participants indicated their current monthly salary and were asked to compare it with two reference groups: friends and colleagues (1) and other people doing a similar job (2). The scale for wage comparison ranged from 1 to 10 and was labeled "I earn decisively less than..." at the low end and "I earn decisively more than..." at the high end. Afterward, the research participants filled in a set of standardized tools, slightly different in both samples. For the analysis in the current study, the following scales were considered:

The Working Conditions Questionnaire (Blanch et al., 2010) in the Polish adaptation by the authors. Before administration, the scale was translated into Polish by the first author and back-translated by a professional translator. Afterward, the second author compared both versions and proposed improvements, which were consulted with the translator and implemented in the final version. Details on the psychometric parameters of the scale will be given in the results section. It is important to note that the Working Conditions Questionnaire was slightly shortened in the international sample. Specifically, the questions from the adjustment to changes subscale were not asked. The reason for the change was the problematic role of the Poland vs. abroad work transition. Because some of the questions in the adjustment to change subscale could be understood as both concerning changes in the current organization and changes between work in the home and host country, the subscale was not used in the migrant sample. 
Two scales measuring work satisfaction by Zalewska (2003), and the Polish version of the Work Satisfaction Scale (Warr et al., 1979). The scales were highly correlated in the Polish sample $(r=.73)$. In the international sample, the research participants filled in only the Work Satisfaction Scale by Warr et al. (1979). The internal consistency results for the work satisfaction scales used (Cronbach's $\alpha$ ) were very high: .96 and .97 for the Warr et al. (1979) scale in the Polish and international sample, and .93 for Zalewska's Work Satisfaction Scale in the Polish sample.

\section{ANALYTICAL APPROACH}

There were two principal aims of the analysis: first, to check whether the structure of the working conditions scale in the Polish version is consistent with the theoretical assumptions made by Blanch et al. (2010); second, to compare the working conditions' and wages' impact on work satisfaction, both in Poland and abroad. To achieve those aims, in the first step, exploratory (EFA) and confirmatory (CFA) factor analyses were conducted for the Polish sample's results of the working conditions questionnaire. The EFA was conducted with the Statistica software package (v. 13), using the principal components extraction method and varimax rotation of the factors. A six-factor structure was assumed, as in the study of Blanch et al. (2010). The CFA was conducted using R software (R Core Team, 2013), using the lavaan package (Rosseel, 2012). In the second step, measurement invariance for the Working Conditions Questionnaire and the Work Satisfaction Scale was assessed using the R software with the lavaan package, for the sake of comparison of results between stayers and migrants. Afterward, objective and subjective wages, working conditions and job satisfaction of migrant and stayers' samples were compared using a multivariate ANOVA (in the Statistica software). Finally, the impact of working conditions and wages on work satisfaction was analyzed with a multiple linear regression, separately for workers in each country (again in Statistica software).

\section{RESULTS}

\section{EXPLORATORY FACTOR ANALYSIS \\ OF THE WORKING CONDITIONS QUESTIONNAIRE}

In the first part, the results of the exploratory factor analysis of the Polish version of the working conditions questionnaire are presented (Table 1).

\section{Table 1}

EFA factor loadings of the Working Conditions Questionnaire

\begin{tabular}{|c|c|c|c|c|c|c|}
\hline \multirow[t]{2}{*}{ Item } & \multicolumn{6}{|c|}{ Factor loadings } \\
\hline & 1 & 2 & 3 & 4 & 5 & 6 \\
\hline $\begin{array}{l}\text { 1. Odpowiada moim zainteresowaniom } \\
\text { [Satisfies my interests] }\end{array}$ & .76 & .11 & .17 & .09 & .14 & .13 \\
\hline $\begin{array}{l}\text { 2. Wymaga ode mnie zgodnie z moimi } \\
\text { umiejętnościami } \\
\text { [Demands of me according to my abilities] }\end{array}$ & .70 & .09 & .17 & .11 & .02 & .12 \\
\hline $\begin{array}{l}\text { 3. Odpowiada moim potrzebom } \\
\text { [Corresponds with my needs] }\end{array}$ & .79 & .16 & .13 & .22 & .05 & .11 \\
\hline $\begin{array}{l}\text { 4. Jest zgodna z moimi oczekiwaniami } \\
\text { [Agrees with my expectations] }\end{array}$ & .79 & .16 & .21 & .22 & .05 & .10 \\
\hline $\begin{array}{l}\text { 5. Pasuje do moich aspiracji } \\
\text { [Fits with my aspirations] }\end{array}$ & .81 & .11 & .21 & .11 & .04 & .10 \\
\hline $\begin{array}{l}\text { 6. Jest zgodna z moimi wartościami } \\
\text { [Conforms with my values] }\end{array}$ & .71 & .20 & .14 & .13 & .06 & .11 \\
\hline $\begin{array}{l}\text { 7. Zapewnia, że moje zasługi są sprawiedliwie } \\
\text { doceniane } \\
\text { [Assures that my qualities are justly appreciated] }\end{array}$ & .71 & .12 & .25 & .16 & .15 & .23 \\
\hline $\begin{array}{l}\text { 8. Stymuluje moje zaangażowanie w pracę } \\
\text { [Stimulates my work engagement] }\end{array}$ & .78 & .17 & .21 & .05 & .06 & .17 \\
\hline
\end{tabular}


Table 1

(Table 1 continued)

\begin{tabular}{|c|c|c|c|c|c|c|}
\hline \multirow[t]{2}{*}{ Item } & \multicolumn{6}{|c|}{ Factor loadings } \\
\hline & 1 & 2 & 3 & 4 & 5 & 6 \\
\hline $\begin{array}{l}\text { 9. Pozwala mi pracować tak, jak lubię } \\
\text { [Allows me to work how I like] }\end{array}$ & .72 & .14 & .04 & .38 & .09 & .15 \\
\hline $\begin{array}{l}\text { 10. Motywuje mnie do pracy } \\
\text { [Motivates me to work] }\end{array}$ & .73 & .14 & .13 & .23 & .11 & .18 \\
\hline $\begin{array}{l}\text { 11. Daje mi poczucie swobody } \\
\text { [Gives me a sense of liberty] }\end{array}$ & .64 & .14 & .01 & .35 & .13 & .18 \\
\hline $\begin{array}{l}\text { 12. Pozwala mi na rozwój osobisty } \\
\text { [Allows for my personal development] }\end{array}$ & .80 & .15 & .14 & .14 & .09 & .15 \\
\hline $\begin{array}{l}\text { 13. Pozwala mi na rozwój moich umiejętności zawodowych } \\
\text { [Allows me to develop my professional competencies] }\end{array}$ & .81 & .13 & .12 & -.01 & .10 & .10 \\
\hline $\begin{array}{l}\text { 14. Daje mi poczucie tożsamości } \\
\text { [Gives me a sense of identity] }\end{array}$ & .80 & .20 & .00 & .13 & .09 & .18 \\
\hline $\begin{array}{l}\text { 15. Pozwala mi czuć się użytecznym } \\
\text { [Allows me to feel useful] }\end{array}$ & .76 & .21 & .02 & .07 & .19 & .18 \\
\hline $\begin{array}{l}\text { 16. Czas pracy (grafik, rytm, przerwy itp.) } \\
\text { [Work time (schedule, rhythm, breaks, etc.)] }\end{array}$ & .19 & .08 & .21 & .73 & .16 & .13 \\
\hline $\begin{array}{l}\text { 17. Ogólna organizacja pracy } \\
\text { [General work organization] }\end{array}$ & .31 & .08 & .32 & .53 & .16 & .27 \\
\hline $\begin{array}{l}\text { 18. Wynagrodzenie } \\
\text { [Financial compensation] }\end{array}$ & .38 & .03 & .48 & .09 & .02 & .06 \\
\hline $\begin{array}{l}\text { 19. Obciążenie pracą } \\
\text { [Workload] }\end{array}$ & .29 & .07 & .21 & .71 & -.05 & .07 \\
\hline $\begin{array}{l}\text { 20. Jakość umowy o pracę } \\
\text { [Quality of work agreement] }\end{array}$ & .27 & .04 & .46 & .29 & .05 & .01 \\
\hline $\begin{array}{l}\text { 21. Równowaga praca - życie osobiste i rodzinne } \\
\text { [Work-life balance] }\end{array}$ & .19 & .03 & .13 & .76 & .17 & .07 \\
\hline $\begin{array}{l}\text { 22. Dostosowuję się do zasad pracy } \\
\text { [I adapt myself to the workplace policy] }\end{array}$ & .19 & .75 & .06 & .11 & .11 & -.02 \\
\hline $\begin{array}{l}\text { 23. Przyjmuję wartości kierownictwa } \\
\text { [I accept the values of the management] }\end{array}$ & .20 & .67 & .12 & .04 & -.01 & .23 \\
\hline $\begin{array}{l}\text { 24. Akceptuję, kiedy mi mówią, jak mam wykonywać } \\
\text { moją pracę } \\
\text { [I accept when they tell me how should I do my work] }\end{array}$ & .13 & .75 & .11 & -.05 & -.08 & .12 \\
\hline $\begin{array}{l}\text { 25. Łatwo przyswajam obowiązujące w firmie normy } \\
\text { [I easily embrace the guidelines established in my } \\
\text { organization] }\end{array}$ & .13 & .77 & .13 & .02 & .15 & -.04 \\
\hline $\begin{array}{l}\text { 26. Utożsamiam się z duchem proponowanych zmian } \\
\text { [I identify with the spirit of proposed changes] }\end{array}$ & .27 & .61 & .20 & .11 & .08 & .22 \\
\hline $\begin{array}{l}\text { 27. Stosuję firmowe procedury w przypadku } \\
\text { wątpliwości o charakterze etycznym } \\
\text { [I apply the company's protocol in case of any } \\
\text { moral dilemma] }\end{array}$ & .17 & .69 & .12 & .04 & .07 & -.06 \\
\hline
\end{tabular}

(Table 1 continues) 
Table 1

(Table 1 continued)

\begin{tabular}{|c|c|c|c|c|c|c|}
\hline \multirow[t]{2}{*}{ Item } & \multicolumn{6}{|c|}{ Factor loadings } \\
\hline & 1 & 2 & 3 & 4 & 5 & 6 \\
\hline $\begin{array}{l}\text { 28. Dostosowuję się do ustalonego grafiku i rytmu } \\
\text { pracy } \\
\text { [I adapt the work schedule and rhythm] }\end{array}$ & .06 & .77 & -.02 & .06 & .14 & .04 \\
\hline $\begin{array}{l}\text { 29. Koleżanki i koledzy } \\
\text { [Camaraderie] }\end{array}$ & .10 & .07 & .10 & .17 & .74 & .00 \\
\hline $\begin{array}{l}\text { 30. Szacunek w grupie roboczej } \\
\text { [Respect in the workgroup] }\end{array}$ & .20 & .13 & .22 & .10 & .79 & .11 \\
\hline $\begin{array}{l}\text { 31. Uznanie własnej pracy przez kolegów } \\
\text { [Acknowledgement of own work by colleagues] }\end{array}$ & .16 & .10 & .17 & .09 & .80 & .13 \\
\hline $\begin{array}{l}\text { 32. Uznanie własnej pracy przez jej odbiorców } \\
\text { [Acknowledgement of own work by its recipients] }\end{array}$ & .13 & .18 & .28 & -.05 & .44 & .30 \\
\hline $\begin{array}{l}\text { 33. Środowisko fizyczne, maszyny i wyposażenie } \\
\text { [Physical environment, machines and equipment] }\end{array}$ & .14 & .18 & .78 & .16 & .18 & .14 \\
\hline $\begin{array}{l}\text { 34. Zasoby techniczne i materiałowe } \\
\text { [Technical and material resources] }\end{array}$ & .18 & .18 & .78 & .17 & .14 & .16 \\
\hline $\begin{array}{l}\text { 35. Zapobieganie ryzykom zawodowym } \\
\text { [Prevention of professional risks] }\end{array}$ & .17 & .16 & .74 & .17 & .16 & .24 \\
\hline $\begin{array}{l}\text { 36. Usługi pomocnicze (czystość, bezpieczeństwo itp.) } \\
\text { [Auxiliary services (cleanliness, security, etc.)] }\end{array}$ & .10 & .20 & .76 & .18 & .25 & .14 \\
\hline $\begin{array}{l}\text { 37. Autonomia w podejmowaniu decyzji zawodowych } \\
\text { [Independence in professional decision-making] }\end{array}$ & .47 & .02 & .29 & .08 & .03 & .52 \\
\hline $\begin{array}{l}\text { 38. Sprawiedliwość procesu zatrudniania, } \\
\text { wynagradzania i awansowania } \\
\text { [Fairness in the process of hiring, remuneration } \\
\text { and promotion] }\end{array}$ & .46 & .09 & .45 & .08 & .14 & .39 \\
\hline $\begin{array}{l}\text { 39. Możliwość ciągłego dokształcania się } \\
\text { [Possibility of continuous training] }\end{array}$ & .57 & .05 & .46 & -.02 & .08 & .32 \\
\hline $\begin{array}{l}\text { 40. Możliwości awansu zawodowego } \\
\text { [Possibility of professional advancement] }\end{array}$ & .57 & -.02 & .45 & -.08 & .08 & .34 \\
\hline $\begin{array}{l}\text { 41. Uczestnictwo w podejmowaniu decyzji } \\
\text { w organizacji } \\
\text { [Taking part in organizational decisions] }\end{array}$ & .52 & .01 & .31 & -.08 & .04 & .56 \\
\hline $\begin{array}{l}\text { 42. Relacje z kierownictwem } \\
\text { [Relations with the management] }\end{array}$ & .33 & .12 & .13 & .23 & .15 & .74 \\
\hline $\begin{array}{l}\text { 43. Ocena efektywności pracy } \\
\text { [Professional performance assessment } \\
\text { by the organization] }\end{array}$ & .38 & .16 & .20 & .18 & .23 & .65 \\
\hline $\begin{array}{l}\text { 44. Wsparcie otrzymywane od kierownictwa } \\
\text { [Support received from the management] }\end{array}$ & .34 & .10 & .26 & .22 & .07 & .70 \\
\hline$\%$ of explained variance & 25.36 & 9.58 & 10.33 & 6.52 & 5.85 & 7.30 \\
\hline
\end{tabular}


Based on the EFA, a six-factor solution, which explained $64.2 \%$ of the total variance, was achieved. The structure resembles to a great extent that of the original (see Blanch et al., 2010), with 6 factors both in original and in Polish solutions. Yet in two cases, a few questions did not load uniquely to the assumed factors (factor loadings below .6), forcing a consideration of a shortened version of the subscales within the CFA. The list of factors with their names (adapted from Blanch et al., 2010) and uniquely fitting questions is presented below.

Radosław

B. Walczak,

Macarena

Vallejo-Martín

- Factor 1: "Personal factors, person-organization fit"; assumed and fitting questions: 1-15.

- Factor 2: "Personal factors, adjustment to change"; assumed and fitting questions: 22-28.

- Factor 3: "Work conditions, technical"; assumed and fitting questions: 33-36.

- Factor 4: "Organizational factors, work regulation"; assumed questions: 16-21, fitting questions: 16, 19, 21.

- Factor 5: "Work conditions, social"; assumed and fitting questions: 29-31.

- Factor 6: "Organizational factors, development potential"; assumed questions: $37-44$, fitting questions: $42-44$.

\section{CONFIRMATORY FACTOR ANALYSIS \\ OF THE WORKING CONDITIONS \\ QUESTIONNAIRE}

The original scale by Blanch et al. (2010) had an assumed two-level structure, with the six factors shown in EFA comprising the first level. On the second level, those factors were grouped in pairs, building a threefactor composition: personal factors (1), organizational factors (2), and work conditions (3), which in turn built the final level of the work conditions total indicator. Because the EFA revealed a 6-factor structure in the Polish sample, such a model was assumed as the base model (1).

The alternative model proposed by Blanch et al. (2010), where the factors converged in pairs, to form a three-factor structure, was assumed as model 2 . Additionally, considering that EFA showed a misfit of certain questions to the original factors, an addi- tional model was assumed, where all the scales were shortened to include only the well fitting items. This approach was named model 3 . The CFA results for all the models are shown in Table 2.

Comparing the indicators of the models, we can observe that models 1 and 3 show acceptable fit criteria (Hu \& Bentler, 1998), with RMSEA not exceeding .06 , SRMR below .08, and CFI above .9. Considering that those indicators should be treated with caution (Kline, 2016), we might note that model 3 performs better than the alternative proposed models, at least in terms of CFI (Chen, 2007), which approaches - but does not exceed -.95 . Consequently, this model was used for further analysis.

\section{MEASUREMENT INVARIANCE BETWEEN \\ WORKERS IN POLAND AND ABROAD}

To evaluate whether the results obtained in Poland and abroad are comparable, a structural invariance CFA (Byrne \& van de Vijver, 2010) was conducted for both samples. Because questions concerning change adjustment were not asked in the migrant sample, the work conditions questionnaire was evaluated in a shortened, five-factor version. The results are shown in Table 3.

The following cut-off criteria, as suggested by Chen (2007), were assumed for model comparisons:

- configural vs. metric invariance: $\triangle \mathrm{CFI}<.010$, $\triangle$ SRMR $<.030, \triangle$ RMSEA $<.015$;

- metric vs. scalar invariance: $\triangle \mathrm{CFI}<.010$, $\triangle$ SRMR $<.010, \triangle$ RMSEA $<.015$.

The obtained results suggest that both the Work Conditions Questionnaire and the Work Satisfaction Scale measurement models are comparable between people working in the home country and abroad.

\section{IMPACT OF THE COUNTRY OF WORK ON WAGES, WORKING CONDITIONS AND JOB SATISFACTION}

After confirmation of the structural adequacy of the measures, the variables of interest were compared for the analyzed groups. In the first part, the descriptive statistics are presented (Table 4).

Table 2

Alternative CFA models for the Working Conditions Questionnaire

\begin{tabular}{lccccc}
\hline Restriction level & $d f$ & $\chi^{2}$ & RMSEA [90\%CI] & SRMR & CFI \\
\hline Model 1 (6 factors, all items) & 847 & 1477.97 & $.055[.051-.060]$ & .067 & .911 \\
Model 2 (3 factors, all items) & 853 & 2295.79 & $.083[.079-.087]$ & .084 & .805 \\
Model 3 (6 factors, limited items) & 727 & 1207.30 & $.052[.047-.057]$ & .064 & .931 \\
\hline
\end{tabular}


Table 3

Measurement invariance between research participants in Poland and abroad

\begin{tabular}{|c|c|c|c|c|c|c|c|c|}
\hline Restriction level & $d f$ & $\chi^{2}$ & RMSEA & $90 \% \mathrm{Cl}$ & SRMR & CFI & $\triangle \mathrm{CFI}$ & \\
\hline \multicolumn{9}{|l|}{ Working Conditions Questionnaire } \\
\hline Base model (PL sample only) & 481 & 1014.71 & .055 & $.051-.060$ & .046 & .944 & & \multirow{10}{*}{$\begin{array}{l}\text { Working } \\
\text { conditions } \\
\text { and work } \\
\text { satisfaction } \\
\text { in Poland } \\
\text { and abroad }\end{array}$} \\
\hline Base model (all samples) & 481 & 1012.33 & .056 & $.051-.060$ & .048 & .945 & .001 & \\
\hline Configural invariance & 1443 & 2322.62 & .069 & $.064-.074$ & .056 & .918 & - & \\
\hline Metric invariance & 1507 & 2406.59 & .068 & $.063-.073$ & .069 & .917 & .001 & \\
\hline Scalar invariance & 1561 & 2558.32 & .069 & $.064-.074$ & .070 & .910 & .007 & \\
\hline \multicolumn{8}{|c|}{ Work Satisfaction Scale (Warr et al., 1979) } & \\
\hline Base model & 97 & 255.54 & .076 & $.065-.087$ & .036 & .958 & - & \\
\hline Configural invariance & 291 & 471.61 & .078 & $.065-.091$ & .040 & .957 & - & \\
\hline Metric invariance & 321 & 512.11 & .076 & $.063-.088$ & .056 & .955 & .002 & \\
\hline Scalar invariance & 351 & 566.88 & .075 & $.063-.086$ & .058 & .952 & .003 & \\
\hline
\end{tabular}

Table 4

Descriptive statistics for the dependent variables analyzed in the study

\begin{tabular}{|c|c|c|c|c|c|c|c|}
\hline & \multirow[t]{2}{*}{ Scale } & \multicolumn{2}{|c|}{$\mathrm{DE}(n=65)$} & \multicolumn{2}{|c|}{ UK $(n=93)$} & \multicolumn{2}{|c|}{$\mathrm{PL}(n=351)$} \\
\hline & & M & $S D$ & M & $S D$ & M & $S D$ \\
\hline Working Conditions total score & $1-5$ & 3.71 & 0.79 & 3.51 & 0.85 & 3.61 & 0.73 \\
\hline $\begin{array}{l}\text { Personal factors: } \\
\text { person-organization fit }\end{array}$ & $1-5$ & 3.50 & 0.93 & 3.24 & 1.09 & 3.38 & 0.90 \\
\hline $\begin{array}{l}\text { Organizational factors: } \\
\text { work regulation }\end{array}$ & $1-5$ & 3.63 & 0.83 & 3.50 & 0.78 & 3.58 & 0.75 \\
\hline $\begin{array}{l}\text { Organizational factors: } \\
\text { development potential }\end{array}$ & $1-5$ & 3.54 & 0.82 & 3.41 & 0.94 & 3.58 & 0.83 \\
\hline Working Conditions, technical & $1-5$ & 3.83 & 0.85 & 3.69 & 0.91 & 3.76 & 0.83 \\
\hline Working Conditions, social & $1-5$ & 3.98 & 0.73 & 3.68 & 0.75 & 3.95 & 0.64 \\
\hline Monthly earnings (in PLN) & $2000+$ & 11434 & 7026 & 7778 & 4134 & 3970 & 2323 \\
\hline $\begin{array}{l}\text { Subjective wage } \\
\text { (vs. others with similar job) }\end{array}$ & $1-10$ & 4.22 & 1.14 & 4.19 & 1.24 & 5.06 & 1.88 \\
\hline Subjective wage (vs. friends) & $1-10$ & 4.48 & 1.23 & 4.43 & 1.43 & 5.54 & 2.06 \\
\hline Warr's Job Satisfaction & $1-5$ & 3.66 & 1.04 & 3.41 & 1.06 & 4.69 & 1.23 \\
\hline
\end{tabular}

Before the analysis, the distribution of the dependent variables was evaluated. Because for almost all variables the distribution was other than normal, a Kruskal-Wallis rank ANOVA was conducted to compare the groups. Results of the analysis are presented in Table 5.

For the following variables, there was a statistically significant difference between the groups: Working Conditions' social conditions subscale, all earn- ings measures (nominal and subjective), and the Job Satisfaction Scale.

To verify the hypothesis that despite having higher nominal wages, migrants evaluate them as subjectively lower, a set of pairwise comparisons was conducted. The results are presented in Table 6 .

Considering the pattern of results (objective wages higher abroad than in Poland, no significant differences between Germany and the UK in this regard; 
Table 5

Kruskal-Wallis' ANOVA results

\begin{tabular}{lrrrrr}
\hline & $\chi^{2}$ & $p$ & \multicolumn{4}{c}{ Mean Rank } \\
\cline { 4 - 6 } & & & PL & DE & UK \\
\hline Working Conditions total score & 3.95 & .139 & 254.48 & 283.91 & 236.76 \\
Personal factors: person-organization fit & 3.00 & .223 & 254.57 & 280.17 & 239.05 \\
Organizational factors: work regulation & 1.33 & .514 & 256.13 & 268.07 & 241.60 \\
Organizational factors: development potential & 2.58 & .276 & 260.45 & 256.71 & 233.24 \\
Working Conditions, technical & 0.75 & .683 & 255.50 & 265.81 & 245.55 \\
Working Conditions, social & 12.33 & .002 & 263.13 & 277.92 & 208.29 \\
Monthly earnings (in PLN) & 184.68 & $<.001$ & 196.44 & 416.67 & 363.03 \\
Subjective wage (vs. others with similar job) & 35.48 & $<.001$ & 280.53 & 197.28 & 198.99 \\
Subjective wage (vs. friends) & 35.93 & $<.001$ & 280.83 & 195.68 & 198.98 \\
Warr's Job Satisfaction & 98.13 & $<.001$ & 298.08 & 174.00 & 149.03 \\
\hline
\end{tabular}

Table 6

Comparison of nominal and subjective wages between stayers and migrants

\begin{tabular}{lcccccc}
\hline & \multicolumn{2}{c}{ PL vs. DE } & \multicolumn{2}{c}{ PL vs. UK } & \multicolumn{2}{c}{ UK vs. DE } \\
\cline { 2 - 7 } & \multicolumn{1}{c}{$Z$} & $p$ & $Z$ & $p$ & $Z$ & $p$ \\
\hline Monthly earnings (expressed in PLN) & 11.09 & $<.001$ & 9.71 & $<.001$ & 2.25 & .051 \\
Subjective wage (vs. others with similar job) & 4.19 & $<.001$ & 4.75 & $<.001$ & 0.07 & .930 \\
Subjective wage (vs. friends) & 4.28 & $<.001$ & 4.77 & $<.001$ & 0.14 & .908 \\
\hline
\end{tabular}

both subjective wage evaluations higher in Poland than abroad, with again no differences between Germany and the UK), the hypothesis can be considered confirmed.

In the last step, the impact of working conditions and wages on work satisfaction was analyzed, with linear regression modeling, separately for each group. The results are presented in Tables 7 and 8 .

The regression models for all the countries were significant. In each country, neither nominal nor the subjective wage evaluations were significant predictors of work satisfaction. At the same time, in all the countries at least two dimensions of Working Conditions were significant predictors of work satisfaction. In each country, it was the Working Conditions' development potential subscale, plus in Germany the Working Conditions scales' "Personal factor: personorganization fit" subscale, in the UK, the Working Conditions' "Organizational factor: work regulation" subscale. In Poland, all dimensions of the Working Conditions Questionnaire were significant predictors of work satisfaction. This confirms the hypoth- esis that the working conditions have a greater impact on work satisfaction than the person's nominal earnings.

\section{DISCUSSION}

The first goal of the study was achieved, as the Working Conditions Questionnaire was proved to have a similar factor structure in the Polish sample as in the original study by Blanch et al. (2010). The only noteworthy difference is that not all items proposed in the original tool fitted uniquely to their initial factors. This may suggest that a shorter version of the tool, without the disputable items, might be more suited for use in future studies. The second part of the study also confirmed the assumed hypotheses to a great extent. The analyzed migrants, despite having a significantly higher level of nominal wages, were less satisfied with their work, as compared with workers in Poland. Two mechanisms can be discussed as explanations for this observation. First, 
Table 7

Regression models' variables, with Work Satisfaction as the dependent variable

\begin{tabular}{|c|c|c|c|c|c|c|c|c|c|}
\hline & \multicolumn{3}{|c|}{ DE } & \multicolumn{3}{|c|}{ UK } & \multicolumn{3}{|c|}{ PL } \\
\hline & $\beta$ & $t(56)$ & $p$ & $\beta$ & $t(84)$ & $p$ & $\beta$ & $t(342)$ & $p$ \\
\hline Intercept & -.95 & -2.76 & .009 & -.53 & -1.28 & .195 & -1.17 & -4.97 & $<.001$ \\
\hline $\begin{array}{l}\text { Nominal earnings } \\
\text { (expressed in PLN) }\end{array}$ & .00 & 1.14 & .094 & .00 & 1.23 & .266 & .00 & 0.26 & .379 \\
\hline $\begin{array}{l}\text { Subjective wage } \\
\text { (vs. others with similar job) }\end{array}$ & .10 & 1.22 & .160 & -.03 & -0.41 & .894 & .03 & 1.51 & .242 \\
\hline Subjective wage (vs. friends) & -.10 & -1.15 & .129 & .00 & 0.01 & .696 & .03 & 1.22 & .215 \\
\hline $\begin{array}{l}\text { Personal factors: } \\
\text { person-organization fit }\end{array}$ & .36 & 3.22 & .021 & .15 & 1.47 & .141 & .44 & 6.52 & $<.001$ \\
\hline $\begin{array}{l}\text { Organizational factors: } \\
\text { work regulation }\end{array}$ & .24 & 1.57 & .114 & .38 & 2.73 & $<.001$ & .28 & 3.52 & $<.001$ \\
\hline $\begin{array}{l}\text { Organizational factors: } \\
\text { development potential }\end{array}$ & .45 & 3.77 & $<.001$ & .44 & 4.27 & $<.001$ & .35 & 5.70 & $<.001$ \\
\hline Working Conditions, technical & .10 & 0.89 & .805 & .09 & 0.84 & .891 & .29 & 5.42 & $<.001$ \\
\hline Working Conditions, social & .11 & 0.85 & .398 & .06 & 0.40 & .926 & .18 & 2.80 & .004 \\
\hline
\end{tabular}

migrants use a different frame of reference for the subjective judgments about their wages, which may partially explain why the wages did not impact their work satisfaction (Brown et al., 2008; Clark et al., 2009). Before going abroad, people may see the wages in the other countries as a strong argument to migrate (Work Service, 2014). Yet once there, this wage appears subjectively lower, because it is compared with earnings of other people in that country. This observation should be treated with caution, as subjective wage evaluations were measured with single-item questions, which may potentially limit their reliability (Gardner et al., 1998). The second explanation of the results relates the lower work satisfaction scores of migrants with the worse working conditions as measured with the Polish version of the Working Conditions Questionnaire. To be more specific, the selected working conditions were a significant predictor of work satisfaction for both migrants and stayers, but the differences in evaluations of working conditions were quite small. Indeed, only the UK subjects evaluated their social working conditions (a subscale of the Working Conditions Questionnaire) as worse compared with the Polish (posthoc $U$-test; $Z=3.28, p=.001$ ) and German (post-hoc $U$-test; $Z=2.88, p=.003$ ) subjects. Lower UK scores in this subscale, which consisted of such items as "Relations with colleagues", "Respect in the workgroup" and "Acknowledging of own work by supervisors", may be related to the shift in attitudes towards foreigners related to Brexit (Rzepnikowska, 2019). Al-
Table 8

Regression models' parameters for each country, with Work Satisfaction as the dependent variable

\begin{tabular}{lccc}
\hline & DE & UK & PL \\
\hline$R$ & .91 & .83 & .86 \\
$R^{2}$ & .83 & .69 & .74 \\
corr. $R^{2}$ & .81 & .66 & .73 \\
$F$ & 34.38 & 23.64 & 119.01 \\
$d f$ & 56 & 84 & 342 \\
$p$ & $<.001$ & $<.001$ & $<.001$ \\
\hline
\end{tabular}

though Brexit was not analyzed in the present study, it may be safe to assume that worsening relations of British-born citizens towards Polish migrants may influence the social relations at work, and in consequence, have a negative impact on work satisfaction. This observation is worth further inquiries.

The present study has some limitations. Firstly, the study design is cross-sectional, which means that the direction of impact cannot be determined. It is possible that the people with lower internal dispositions for work satisfaction choose to migrate for work, and it is those dispositions that cause their lower work satisfaction, rather than the wage evaluations and working conditions abroad. It seems therefore impor-
Working conditions and work satisfaction in Poland and abroad 
tant to control the internal dispositions of migrants and stayers in further studies. An additional important constraint to the study's conclusions is the nonrandom, snowball sampling method (although comparable for migrants and stayers). The sample in the study is relatively young (33 years old on average) and has an over-representative access to the internet and the social media. The data from non-internet users in the sample is rather anecdotal (a few cases in the Polish and German samples inputted by the respondent's friends). A consequence may be slightly better working conditions and higher wages in the sample, compared with the general population. Although the abovementioned specifics should be true for both samples (migrants and stayers), it may be difficult to verify such an assumption solely on the basis of the present data.

\section{CONCLUSIONS}

The study shows three important things. Firstly, the Polish version of the Working Conditions Questionnaire is an internally consistent and reliable tool for measuring work properties. Secondly, higher nominal wages of migrants do not lead to their higher work satisfaction. Thirdly, working conditions are a better predictor of work satisfaction of migrants and stayers than their wages.

\section{ACKNOWLEDGMENTS}

The study is a result of a cooperation agreement between Opole University and Malaga University. The project had no external funding.

\section{References}

Baka, Ł. (2018). Mechanizmy kształtowania się zdolności do pracy w świetle modelu wymagania w pracy - zasoby [Process of work ability development in the light of job demands-resources model]. Czasopismo Psychologiczne, 24, 481-490. https://doi.org/10.14691/CPPJ.24.3.481

Bakker, A. B., \& Demerouti, E. (2017). Job demandsresources theory: Taking stock and looking forward. Journal of Occupational Health Psychology, 22, 273-285. https://doi.org/10.1037/ocp0000056

Bańka, A., Wołoska, A., \& Bazińska, R. (2002). Polska wersja Meyera i Alen Skali Przywiązania do Organizacji [Polish version of Meyer and Allen's Organizational Commitment Scales]. Czasopismo Psychologiczne, 8, 65-74.

Blanch, J. M., Sahagun, M., \& Cervantes, G. (2010). Estructura Factorial del Cuestionario de Condiciones de Trabajo [Factor structure of Working
Conditions Questionnaire]. Revista de Psicología del Trabajo y de las Organizaciones, 26, 175-189.

Brown, G. D., Gardner, J., Oswald, A. J., \& Qian, J. (2008). Does wage rank affect employees' well-being? Industrial Relations, 47, 355-389. https://doi. org/10.1111/j.1468-232X.2008.00525.x

Byrne, B. M., \& van de Vijver, F. J. R. (2010). Testing for measurement and structural equivalence in large-scale cross-cultural studies: Addressing the issue of nonequivalence. International Journal of Testing, 10, 107-132. https://doi.org/10.1080/ 15305051003637306

Chan, S. H., \& Qiu, H. H. (2011). Loneliness, job satisfaction, and organizational commitment of migrant workers: Empirical evidence from China. The International Journal of Human Resource Management, 22, 1109-1127. https://doi.org/10.1080/09 585192.2011 .556785

Chen, F. F. (2007). Sensitivity of goodness of fit indexes to lack of measurement invariance. Structural Equation Modeling, 14, 464-504. https://doi. org/10.1080/10705510701301834

Clark, A. (2011). Happiness, habits and high rank: Comparisons in economic and social life. Retrieved from https://papers.ssrn.com/sol3/papers.cfm?abstract_ id $=2131154$

Clark, A. E., Kristensen, N., \& Westergaard-Nielsen, N. (2009). Job satisfaction and co-worker wages: Status or signal? The Economic Journal, 119, 430-447. https://doi.org/10.1111/j.1468-0297.2008.02236.x

Cohrs, J. C., Abele, A. E., \& Dette, D. E. (2006). Integrating situational and dispositional determinants of job satisfaction: Findings from three samples of professionals. The Journal of Psychology, 140, 363395. https://doi.org/10.3200/JRLP.140.4.363-395

Gardner, D. G., Cummings, L. L., Dunham, R. B., \& Pierce, J. L. (1998). Single-item versus multipleitem measurement scales: an empirical comparison. Educational and Psychological Measurement, 58, 898-915. https://doi.org/10.1177/001316449805 8006003

Hackman, J. R., \& Oldham, G. R. (1980). Work redesign. Boston, MA: Addison-Wesley Publishing Company.

Herzberg, F. (1973). Work and the nature of man. Signet. Hodson, R. (1997). Group relations at work: Solidarity, conflict, and relations with management. Work and Occupations, 24, 426-452. https://doi.org/10. 1177/0730888497024004003

Hombrados-Mendieta, I., \& Cosano-Rivas, F. (2013). Burnout, workplace support, job satisfaction and life satisfaction among social workers in Spain: a structural equation model. International Social Work, 56, 228-246. https://doi.org/10.1177/ 0020872811421620

Hu, L., \& Bentler, P. M. (1998). Fit indices in covariance structure modeling: Sensitivity to underparameterized model misspecification. Psychological 
Methods, 3, 424-453. https://doi.org/10.1037/1082989X.3.4.424

Hulin, C. L. (1969). Source of variation in job and life satisfaction: The role of community and job-related variables. Journal of Applied Psychology, 53, 279-291. https://doi.org/10.1037/h0027853

Itzhaki, M., Ea, E., Ehrenfeld, M., \& Fitzpatrick, J. J. (2013). Job satisfaction among immigrant nurses in Israel and the United States of America: Job satisfaction of immigrant nurses. International Nursing Review, 60, 122-128. https://doi.org/10.1111/j.14667657.2012.01035.x

Judge, T. A., Piccolo, R. F., Podsakoff, N. P., Shaw, J. C., \& Rich, B. L. (2010). The relationship between pay and job satisfaction: a meta-analysis of the literature. Journal of Vocational Behavior, 77, 157-167. https://doi.org/10.1016/j.jvb.2010.04.002

Judge, T. A., \& Watanabe, S. (1993). Another look at the job satisfaction-life satisfaction relationship. Journal of Applied Psychology, 78, 939-948. https:// doi.org/10.1037/0021-9010.78.6.939

Kahneman, D., \& Deaton, A. (2010). High income improves evaluation of life but not emotional wellbeing. Proceedings of the National Academy of Sciences, 107, 16489-16493. https://doi.org/10.1073/ pnas. 1011492107

Kline, R. B. (2016). Principles and practice of structural equation modeling ( $4^{\text {th }}$ ed.). Guilford Press.

Kostrzewa, Z., \& Gudaszewski, G. (2019). Informacja o rozmiarach i kierunkach czasowej emigracji z Polski w latach 2004-2018 [Information on the size and directions of temporary emigration from Poland in 2004-2018]. Retrieved from https://stat.gov.pl/ download/gfx/portalinformacyjny/pl/defaultaktualnosci/5471/2/12/1/informacja_o_rozmiarach_i_ kierunkach_czasowej_emigracji_z_polski_w_latach_2004-2018.pdf

Leider, R., \& Buchholz, S. (1995). The rustout syndrome. Training \& Development, 49, 7-10.

Lubrańska, A. (2011). Klimat organizacyjny a doświadczanie wypalenia zawodowego [Organizational climate and burnout syndrome]. Medycyna Pracy, 62, 623-631.

Massey, D. S., Arango, J., Hugo, G., Kouaouci, A., Pellegrino, A., \& Taylor, J. E. (1993). Theories of international migration: a review and appraisal. Population and Development Review, 19, 431-466. https://doi.org/10.2307/2938462

Meyer, J. P., \& Allen, N. J. (1991). A three-component conceptualization of organizational commitment. Human Resource Management Review, 1, 61-89. https://doi.org/10.1016/1053-4822(91)90011-Z

Muchinsky, P. M. (1977). Organizational communication: Relationships to organizational climate and job satisfaction. Academy of Management Journal, 20, 592-607. https://doi.org/10.5465/255359

Mudor, H. (2011). Conceptual framework on the relationship between human resource management practices, job satisfaction, and turnover. Journal of Economics and Behavioral Studies, 2, 41-49. https://doi.org/10.22610/jebs.v2i2.220

Peiró, J. M., Agut, S., \& Grau, R. (2010). The relationship between overeducation and job satisfaction among young Spanish workers: The role of salary, contract of employment, and work experience. Journal of Applied Social Psychology, 40, 666-689. https://doi.org/10.1111/j.1559-1816.2010.00592.x

Portes, A., Guarnizo, L. E., \& Landolt, P. (1999). The study of transnationalism: Pitfalls and promise of an emergent research field. Ethnic and Racial Studies, 22, 217-237. https://doi.org/10.1080/014198799329468

Pujol-Cols, L., \& Dabos, G. E. (2019). Dispositional and situational factors at work: a validation of scales and examination of effects on job satisfaction. Academia Revista Latinoamericana de Administración (ahead-of-print). https://doi.org/10.1108/ ARLA-12-2017-0355

Qin, X., Hom, P., Xu, M., \& Ju, D. (2014). Applying the job demands-resources model to migrant workers: Exploring how and when geographical distance increases quit propensity. Journal of Occupational and Organizational Psychology, 87, 303-328. https:// doi.org/10.1111/joop. 12047

R Core Team. (2013). R: a language and environment for statistical computing. The $\mathrm{R}$ Foundation. Retrieved from http://www.R-project.org/

Rosseel, Y. (2012). Lavaan: an R package for structural equation modeling and more. Version 0.5-12 (Beta). Journal of Statistical Software, 48, 1-36. https://doi.org/10.18637/jss.v048.i02

Rzepnikowska, A. (2019). Racism and xenophobia experienced by Polish migrants in the UK before and after Brexit vote. Journal of Ethnic and Migration Studies, 45, 61-77. https://doi.org/10.1080/136 9183X.2018.1451308

Sjaastad, L. A. (1962). The costs and returns of human migration. Journal of Political Economy, 70, 80-93. https://doi.org/10.1086/258726

Spector, P. E. (1997). Job satisfaction: Application, assessment, causes, and consequences. Sage Publications.

Szostek, D., \& Glińska-Neweś, A. (2017). Identyfikacja wymiarów jakości relacji interpersonalnych w organizacji [Identification of the quality's dimensions of interpersonal relationships in the organization]. Organizacja i Kierowanie, 3, 11-24.

Taris, T. W., \& Schreurs, P. J. G. (2009). Well-being and organizational performance: an organizational-level test of the happy-productive worker hypothesis. Work \& Stress, 23, 120-136. https://doi. org/10.1080/02678370903072555

Vroom, V. H. (1967). Work and motivation. John Wiley \& Sons.

Walczak, R. (2013). What do young educated workers want? The impact of work enrichment components on the perceived job satisfaction. In M. Seitl \& L. Vavrysova (Eds.), Psychologie práce a organiza-
Working conditions and work satisfaction in Poland and abroad 
Radosław

B. Walczak,

Macarena

Vallejo-Martín ce 2013: Sborník mezinárodní konference [Psychology of Work and Organization 2013: Proceedings of the International Conference] (pp. 194-201). Palacký University Olomouc.

Walczak, R. (2016). Wage level or internal dispositions - what is more important in determining the satisfaction of employees on different positions? In P. Slavíčková (Ed.), Knowledge for market use 2016: Our interconnected and divided world (pp. 580-587). Palacký University Olomouc.

Walczak, R. (2017). Why do objective wage levels have lesser impact than relative earnings on work satisfaction? Comparison of objective and subjective work evaluations in the context of job choice decisions. In P. Slavíčková (Ed.), Knowledge for market use 2017: People in economics - decisions, behavior and normative models (pp. 532-539). Palacký University Olomouc.

Wang, Z., \& Jing, X. (2018). Job satisfaction among immigrant workers: a review of determinants. Social Indicators Research, 139, 381-401. https://doi. org/10.1007/s11205-017-1708-z

Warr, P., Cook, J., \& Wall, T. (1979). Scales for the measurement of some work attitudes and aspects of psychological well-being. Journal of $\mathrm{Oc}^{-}$ cupational Psychology, 52, 129-148. https://doi. org/10.1111/j.2044-8325.1979.tb00448.x

Weiss, H. M. (2002). Deconstructing job satisfaction. Human Resource Management Review, 12, 173-194. https://doi.org/10.1016/S1053-4822(02)00045-1

Winchie, D. B., \& Carment, D. W. (1989). Migration and motivation: The migrant's perspective. International Migration Review, 23, 96-104. https://doi. org/10.1177/019791838902300105

Work Service (2014). Migracje zarobkowe Polaków [Labor migrations of Poles]. Retrieved from http://www. workservice.com/pl/content/download/3852/30713/ file/Raport\%20Work\%20Service\%20-\%20Migracje\%20zarobkowe\%20Polak\%C3\%B3w.pdf

Wrench, J., Rea, A., \& Ouali, N. (2016). Migrants, ethnic minorities and the labour market: Integration and exclusion in Europe. Springer.

Wright, T. A., \& Cropanzano, R. (2007). The happy/productive worker thesis revisited. In J. J. Martocchio (Ed.), Research in personnel and human resources management (Vol. 26, pp. 269-307). Emerald Group Publishing Limited.

Yao, C., Thorn, K., Duan, Z., \& Taskin, N. (2015). Workplace stress in a foreign environment: Chinese migrants in New Zealand. Equality, Diversity and Inclusion, 34, 608-621. https://doi.org/10.1108/EDI08-2014-0065

Zalewska, A. (2003). Skala Satysfakcji z Pracy - pomiar poznawczego aspektu ogólnego zadowolenia $z$ pracy [The Satisfaction with Job Scale - a measure of cognitive aspect of overall job satisfaction]. Retrieved from http://repozytorium.uni. lodz.pl:8080/xmlui/handle/11089/3708
Zdybek, P., \& Walczak, R. (2009). Badania nad rzetelnością i trafnością Kwestionariusza Oceny Dobrostanu Psychicznego [Research on the validity and reliability of the Psychological Wellbeing Questionnaire]. In A. Oleszkowicz \& P. Zdybek (Eds.), Psychologia ilości, psychologia jakości. Uzupetniajace się spojrzenia [Quantitative psychology, qualitative psychology. Two supplementary outlooks] (pp. 103-120). Atut. 